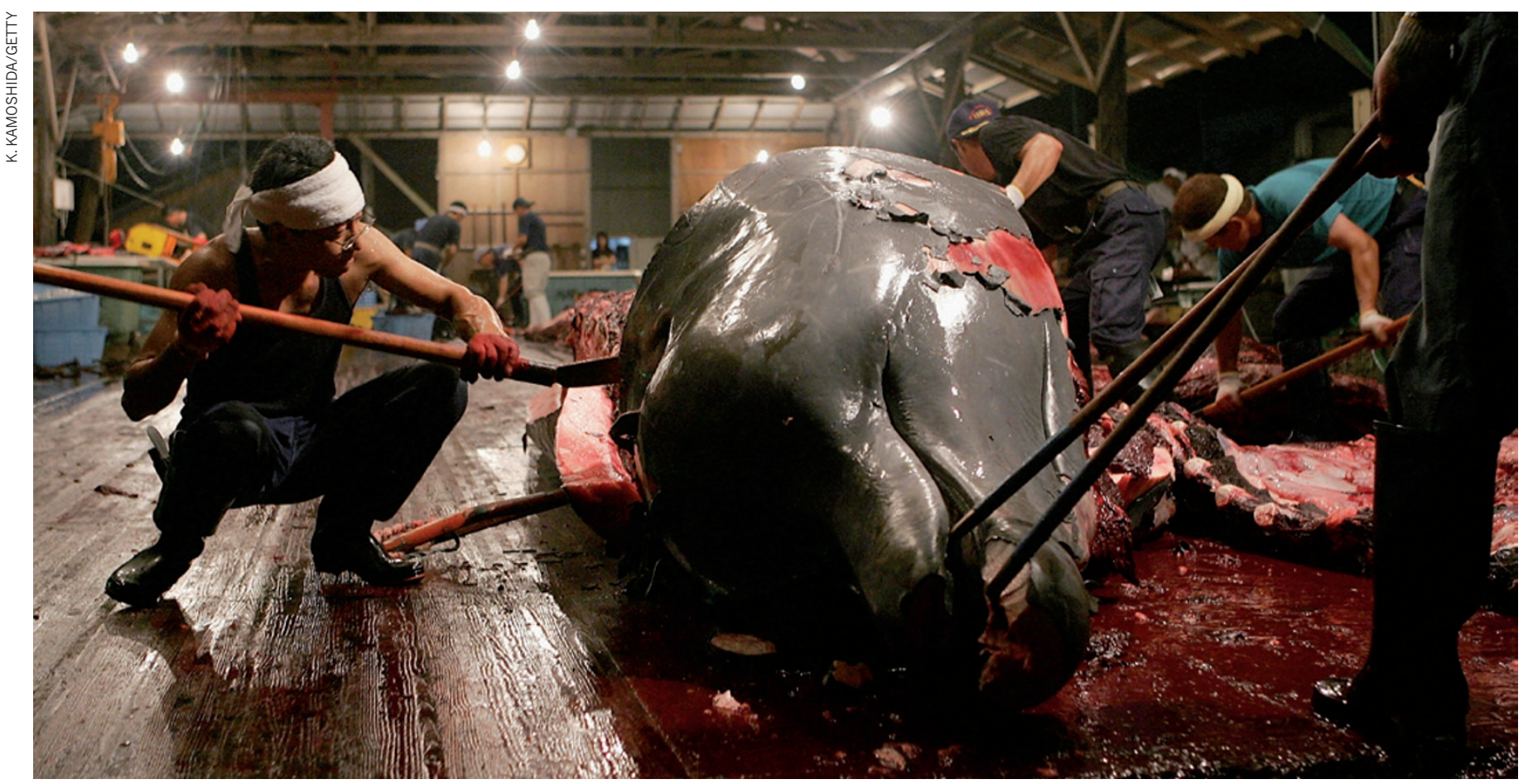

Introducing tradeable permits for commercial whaling could actually reduce the number of whales that are caught by countries including Japan.

\title{
A market approach to saving the whales
}

\section{The future of the International Whaling Commission is tenuous. A 'whale conservation market' might rescue it, say Christopher Costello, Leah R. Gerber and Steven Gaines.}

$\mathrm{D}$ espite the International Whaling Commission's (IWC) moratorium on commercial whaling beginning in 1986, the number of whales taken has more than doubled since the early 1990s. Almost 2,000 whales are now harvested each year - roughly 1,000 for 'scientific purposes' (by Japan), 600 by countries that object to the ban (Norway and Iceland), and 350 for subsistence (mainly by Denmark, Russia and the United States) $)^{1}$. Many populations of large whales have been severely depleted and continue to be threatened by commercial whaling ${ }^{2}$.

The persistence of largely unregulated whaling has sparked heated debate about whether the IWC, long hamstrung by management and ethics issues, should again permit formally sanctioned whaling. In 2010, some anti-whaling nations proposed a compromise: establishing quotas for sanctioned whaling that would still reduce the overall number of whales taken. After much wrangling, the deal fell through - largely because many anti-whaling groups had a fundamental problem with setting quotas at all, because they felt that these would appear to legitimize commercial whaling. Some people blame Japan for the deal's collapse, because the country refused to sign up to a proposed zero quota on whale catches in the Southern Ocean.

We propose an alternative path forward that could break the deadlock: quotas that can be bought and sold, creating a market that would be economically, ecologically and socially viable for whalers and whales alike. Because conservationists could bid for quotas, whalers could profit from whales even without harvesting the animals. A market would therefore open the door to reducing mortality without needing to battle over whether whaling is honourable or shameful.

\section{TRIED AND TESTED}

Market approaches to environmental protection have expanded substantially over the past 20 years. When carefully designed, they can be remarkably successful. Emissions trading markets for air pollutants such as sulphur dioxide and nitrogen oxides have reduced emissions more, and at a lower cost, than traditional regulations in the United States. Conservation and wetland mitigation-banking programmes have resulted in more than 200,000 protected acres of habitat and have catalysed investment in conservation by the private sector. And fisheries managed with individual transferable quotas, in which sustainable levels of catch are divided and traded between permit-holding fishermen, in countries such as New Zealand, Iceland and Canada, have simultaneously allowed fisheries to continue and stopped stocks from collapsing.

The concept of auctioning annual whale catch quotas through a 'World Whaling Authority' was suggested in 1982 (ref. 3). It was never implemented, however, perhaps because the concept was ahead of its time (the first such tools - in fisheries, air pollution and biodiversity - were not established until the 1990s), and perhaps because it would have required whalers to purchase a privilege that they were used to receiving for free. 
A whale-conservation market would be different. In such a system, 'whale shares' would be allocated in sustainable numbers to all member nations of the IWC, who would have the choice of exercising them, leaving them unused for a year or retiring them in perpetuity. The shares would be tradable in a carefully controlled global market, perhaps with the restriction that members could not trade whale products with non-members. The number of whales hunted would depend on who owned the shares. At one extreme (in which whalers purchase all the shares), whales would be harvested to the agreed sustainable level. At the other extreme (where conservationists purchase all the shares), all whales would be protected from harvest.

There are multiple challenges in getting such a scheme to work, including agreeing on sustainable quotas and on how shares should be allocated. We believe that the IWC is up to the task.

\section{KILLER QUESTION}

Various well-established algorithms could be used to identify sustainable harvest levels for whales ${ }^{4}$. For example, the IWC's 'catch limit algorithm', which sets commercial quotas for baleen whales, could be applied more broadly. The US Marine Mammal Protection Act mandates a more conservative approach, known as 'potential biological removal', to establish sustainable take levels for marine mammals in US waters. Although negotiations to set binding catch quotas, such as the deliberations by IWC members in 2010, have not led to consensus, the major reason has not been objections to the proposed quota numbers per se, but a more philosophical objection to the idea of setting quotas at all. Allowing the quotas to be traded, as we advocate, means that they would not necessarily lead to whale deaths or national caps on takes, appeasing both parties.

The initial allocation of whale shares is a potentially challenging issue. In the realm of climate change, the process of divvying up global emissions targets into national responsibilities has proven intractable, with developing nations arguing that stringent targets will inhibit growth, and others arguing that their circumstances, from particularly cold winters to vast forests acting as carbon sinks, justify higher targets. Allocation has been contentious in fisheries too, where it gives a highly valuable asset to the recipient. In practice, in both the emissions and fisheries markets, the initial allocations almost always coincide with historical use. Research into the global markets for air pollutants ${ }^{5}$ and fish $^{6}$ offers many potential solutions to the whaling allocation problem. One possibility would be to divide the majority of the quota between whaling and non-whaling nations based on historical whaling patterns, leaving the rest for open auction, the proceeds of which would go to whale conservation.

Handing out shares within nations has had a greater history of success, and is likely to be less contentious. Initial allocations within non-whaling countries would probably go to conservation trusts that are focused on protecting particular species. Quota rights could be limited in duration, say for ten years with the possibility of renewal, or in perpetuity for subsistence groups.

Policing such a market would not be simple. But a global vessel registry and carefully monitored trading would help to ensure system integrity. Requiring prices and trades to be made public would bring transparency to an industry that has long been accused of back-room deals and vote trading.

The 'whale share' approach stands a good chance of being acceptable both to anti- and to pro-whaling constituents. If quotas are set properly, transactions would reduce the number of whales harvested, quite possibly to zero, unlike existing protocols, which seem to be increasing the catches. Whalers would be suitably compensated. And because trades are voluntary, the market would have the potential to make all parties better off, and simultaneously improve whale conservation.

A fervent anti-whaler will be quick to argue that you cannot and should not put a price on the life of a whale; a species should be protected irrespective of its economic value. But unless all nations can be convinced or forced to adopt this view, whaling will continue. It is precisely because of the lack of a real price tag in the face of different values that anti-whaling operations have had such limited success.

A generous estimate of the total annual profit from all global commercial whaling activity is US\$31 million. Whalers spend millions of dollars to harvest these whales, many of which are then sold on global markets. Recent reports suggest that even some whales hunted for subsistence may end up

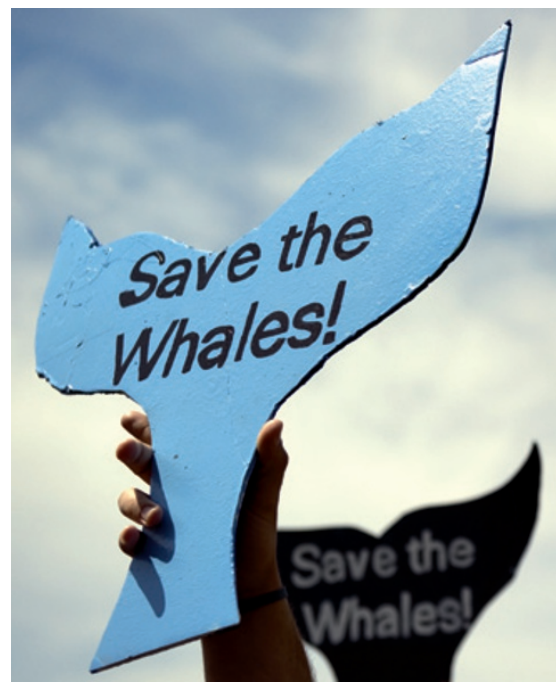

In a market system, charities could 'buy' whales, rather than spending money campaigning. for sale elsewhere ${ }^{7}$, suggesting that whale meat is replaceable as a necessary source of protein for some communities.

Simple calculations based on current market prices, whale sizes and whaling costs, suggest that the per-whale profit for whalers is in the ballpark of $\$ 13,000$ for a minke whale to $\$ 85,000$ for a fin whale. Whale prices should therefore be within reach of conservation groups and even some individuals.

A conservative estimate of the amount spent annually by non-profit organizations on anti-whaling (based on the expenditures of Greenpeace USA, Greenpeace Interna-

"If quotas are set properly, transactions tional, Sea Shepherd Conservation Society, WWF International would reduce the number of whales harvested." and WWF UK) is \$25 million. Rather than supporting antiwhaling protests and movements (and their accompanying carbon footprint), this money could be used to purchase whales, arguably with the same or better effect. Sea Shepherd, for example, estimates that its multimillion-dollar 2008 campaign saved about 350 minke whales in Antarctic waters. By our calculations, those whales could have been purchased for less than $\$ 4$ million.

Properly designed, a whale market could accommodate important concerns such as the by-catch of whales in fisheries or whale ship strikes. It could even be integrated with other market approaches, such as a recent proposal to apply carbon credits to live whales ${ }^{8}$. By placing an appropriate price tag on the life of a whale, a whale conservation market provides an immediate and tangible way to save them.

Christopher Costello and Steven Gaines are at the Bren School of Environmental Science and Management, University of California, Santa Barbara, California 93106, USA. Leah R. Gerber is in the Ecology, Evolution and Environmental Sciences faculty, School of Life Sciences, Arizona State University, Tempe, Arizona 85281, USA.

e-mail:costello@bren.ucsb.edu

1. International Whaling Commission Catch Limits \& Catches Taken; available at http://go.nature. com/rcnfa5

2. Gerber, L. R., DeMaster, D. \& Roberts, S. Am. Sci. 88, 316-324 (2000).

3. Clark, C. W. \& Lamberson, R. Mar. Pol. 6 , 103-120 (1982).

4. Haltuch, M. A., Punt, A. E. \& Dorn, M. W. Fish. Res. 100, 42-56 (2009)

5. Goulder, L., Hafstead, M. \& Dworsky, M. J. Environ. Econ. Manage. 60, 161-181 (2010).

6. Anderson, T., Arnason, R. \& Libecap, G. Annu. Rev Res. Econ. 3, 159-179 (2011)

7. Black, R. Greenland whale hunt 'commercial' BBC News (17 June 2008); available at http:// go.nature.com/vspyd5

8. Pershing, A. J. et al. PLoS ONE 5, e12444 (2010). 